This is a self-archived version of an original article. This version may differ from the original in pagination and typographic details.

Author(s): Rantamäki, Niina; Kattilakoski, Mari

Title: On the trail of local welfare innovations in rural Finland

Year: 2019

Version: Accepted version (Final draft)

Copyright: ㄷ 2019 The Author(s), Regional Science Policy and Practice and RSAI

Rights: In Copyright

Rights url: http://rightsstatements.org/page//nC/1.0/?language=en

Please cite the original version:

Rantamäki, N., \& Kattilakoski, M. (2019). On the trail of local welfare innovations in rural

Finland. Regional Science Policy \& Practice, 11(2), 329-343. https://doi.org/10.1111/rsp3.12213 


\title{
On the trail of Local Welfare Innovations in Rural Finland
}

\author{
M.A. Soc. Sc., PhD student Niina Rantamäki \\ University of Jyväskylä, Kokkola University Consortium Chydenius \\ e-mail: niina.rantamaki@,chydenius.fi \\ P.O. Box 567
}

FI-67701 Kokkola

Finland

L.Soc.Sc, PhD student Mari Kattilakoski

University of Eastern Finland, Karelian Insitute

e-mail: mari.kattilakoski@uef.fi

P.O. Box 111

FI-80101 Joensuu

Finland

\section{Acknowledgement}

We would like to thank the Rural Policy Committee in Finland for financing the research project and M.A. Soc. Sc., PhD student Maija Halonen for drawing up the map of Finland. 


\section{Introduction}

As with the welfare state more broadly, the Finnish system, generally considered as representative of the Nordic welfare state regime (see Esping-Andersen, 1990), has faced serious threats over the past two decades. The challenges are related to the parallel developments including demographic changes, the decline in public finances and an ideological shift from a shared responsibility to an individual rights discourse and workfare regime of welfare (e.g. Kuivalainen \& Niemelä, 2010; Milbourne, 2010). Together these have undermined the foundation of traditional universal model created to offer a high degree of social protection including public social and health care services to all the citizens. Solutions to the existing problems have been sought by improving the competitiveness of the national economy and thus strengthening the funding base of welfare state. In addition, structural measures with an aim to lower costs in tandem with improving the availability, efficiency and quality of welfare services have been carried out. (Andre \& Garcia, 2014; see also Kröger, 2011; Niemelä \& Saarinen, 2012.)

The remote rural areas of Finland, characterized by low population density and long distances, are the most affected by the developments threatening the survival of the welfare state as well as by the partly conflicting efforts to save it (e.g. Satka \& Hämeenaho, 2015; see also Bock 2016). In addition, the rapidly ageing population, the structural changes in agriculture, and the decrease of municipal tax revenues, partly caused by the two above mentioned developments, have made it difficult for many rural municipalities to sustain services they are legally responsible for (Hänninen \& Silvasti, 2010). Along with the pressure on services, administrative reforms have led to the diminution of democratic decision-making processes and thus weakened the possibilities of rural residents' voices being heard (e.g. Häikiö, 2010; Matthies, Kattilakoski, \& Rantamäki 2011; Närhi \& Kokkonen 2014). The reforms include measures as reducing the number of municipalities to take 
advantage of the economies of scale, transferring the responsibility of providing public services from local authorities to autonomous regional organisations, rationalising the processes of service delivery including introduction of e-services and self-services as well as contracting the provision of certain services out to private service providers (see Valtioneuvosto, 2018).

However, at the same time, as a response to current policy, there are rural communities that have developed their own ways for organising local services and improving the welfare of local residents (e.g. Haverinen \& Ilmarinen, 2008; Matthies \& Rantamäki, 2013; Milbourne, 2010). Based on Brandsen, Evers and Cattacin's (2016, pp. 6-7) definition of social innovations, we define these new generation of ideas or courses of actions as local welfare innovations "that are created mainly by networks and joint action in social realms beyond business and government routines, at any given moment, (they) raise the hope and expectations of progress towards something "better" (e.g. more socially sustainable/democratic/effective society)". The definition emphasizes the twofold social dimension of these innovative solutions as the end and the means as noted by Murray, Caulier-Grice and Mulgan (2010, p. 6): simultaneously they meet social needs and they create new social relationships and collaborations both inside and outside the community.

To find out how these rural communities, often perceived as "vulnerable" (e.g. Freshwater, 2015), have in their cases managed to change the direction of mainstream development, we will review two of them more closely. The municipality of Sievi and the village of Ullava ${ }^{1}$ are both rural communities where residents have taken an active role in developing services that meet their daily welfare needs. While aiming to identify the factors related to the emergence of the local welfare innovations in rural Finland, we will piggyback on the theory of "local welfare systems" by Andreotti, Mingione and Polizzi (2012). Furthermore, based on the longitudinal case study research

\footnotetext{
${ }^{1}$ Municipality is a self-governing unit that represents the local level of administration in Finland. As for a village refers to a clustered human settlement or community that does not have such an official role.
} 
carried out during 2009-2016, we will propose a set of policy measurements to address the withdrawal of welfare services from the rural areas. In this regard, the goal of the article is twofold: to understand the factors contributing to the development of social innovations addressing welfare needs at a local context, and based on that, to reflect on the measures that are required at the policy level with a view to secure and improve the welfare of rural communities.

We begin by discussing the idea of social innovation and placing it in the context of local welfare systems. Next we present the research design including the research localities and the processes of data collection and analysis. We then move on to the results by introducing the developments that have taken place in Sievi and Ullava and the conditions identified contributing to the emergence of local welfare innovation. After that, we shortly contemplate the aspects related to the generalization of the results. At the end, we reflect on the perspectives to be considered at the level of welfare policy.

\section{Social innovation in the context of local welfare systems}

The origin of the concept of social innovation may be traced to the turn of 1970 to 1980 's when it was used to refer to grass roots initiatives that aimed to provide an alternative to public social services that were incapable to meet local welfare needs. This represents a 'radical perspective' on social innovation as local initiatives that challenge the existing power relations, empower people and promote equality. During the past decades, the concept has been increasingly applied within the political mainstream discourse both at the EU and national levels. In this context social innovation has gained a more functionalist meaning as cost-efficient solutions that are sought for responding the socially recognized needs in times of crises (e.g. Bock, 2016; Brandsen et al., 2016; Häikiö, Fraisse, Adam, Jolanki, \& Knutagård, 2017). The division is naturally simplified, but it demonstrates that regarding social innovation there are various and partly contradictory desires and 
expectations which according to Montgomery (2016) also reflect a broader conflict between neoliberalism and its opponents.

The above described reflects the differences between the holistic and reductionist perspectives on social innovation (see TEPSIE, 2014). At the centre of both approaches are social needs reflecting societal flaws and the gap between what there is and what there ought to be, as well as the pursuit of social value instead of individual benefits. However, while the reductionist interpretation lays more emphasises to the 'product' dimension of social innovation defining them as "new ideas that work in meeting social goals" (Mulgan, Tucker, Ali, \& Sanders, 2007, p. 8), the holistic approach focuses on both the dimension of process and outcome (e.g. Brandsen et al., 2016; Moulaert, MacCallum, Mehmood \& Hamdouch, 2014; Nicholls \& Murdock, 2012). Under the circumstances, the interpretations differ how much attention they pay to the way the outcome is achieved and the more structural causes that lie behind the social needs. Unlike the reductionist approach, the holistic one highlights the significance of the participation of various stakeholders and the emergence of new social relationships and collaboration throughout the process. In addition to innovative activities, products or services created it directs attention to social consequences including collective empowerment and broader societal transformation (see also Moulaert et al., 2014; TEPSIE, 2014).

The need and demand for social innovation are tightly related to the discussion concerning community resilience which puts a focus on the responsive capacities of places and social systems facing different kinds of threats; resilience is about the prevalent ability of a community to evolve and adapt to ongoing changes as well as to sustain well-being in the face of continuing adversity (Cheshire, Esparcia \& Shucksmith, 2015; Robinson \& Carson, 2016). In this context social innovation highlights the transformative quality of resilience which is often seen as a more positive response by a community: not only to survive but also to change and grow after a shock. As with 
social innovation, the idea of resilience has also been criticised (MacKinnon \& Derickson, 2012; Robinson \& Carson, 2016) for focusing mainly on the inherent qualities of local communities, which sustains the vulnerability of marginalized communities instead of aiming to transform the social relations and inequitable distribution of material resources. MacKinnon and Derickson (2012) have suggested that resilience should be replaced by the politics of resourcefulness that shifts attention to the social relations within politics and economy that form the capacities of communities to mobilize their resources.

As Bock (2016) stated, from the rural perspective "the Janus face" essence of social innovation (see Häikiö et al., 2016) is interesting because it emphasizes the significance of social and relational aspects for rural development. Approaching social innovation from the context of local welfare systems (LWS) (Andreotti et al., 2012) makes both aspects visible. While rooted in the theories of complexity, LWS reviews the welfare of people living in a particular context as a diverse and multidimensional system consisting of different elements and progressions which both contribute to the creation of welfare needs but that simultaneously provide resources to satisfy them. Thus LWS represents a kind of intersection or grass roots manifestation where national and global influences meet the local circumstances together with human actors and structural factors.

Based on the above, we claim that the holistic or the more radical perspective of social innovation that emphasizes the dimension of participatory democracy is in a way in-built in the idea of LWS: while it reflects the presence of technocratic thought inherent to neoliberal policy agenda, it is primarily committed to social transformation from the bottom up (see Häikiö et al., 2017; Montgomery, 2016). From this perspective, in addition to a broader societal frame, crucial for welfare innovation are specific geographical, cultural, and socioeconomic conditions. They evolve over time and give rise to different welfare needs as well as create resources to meet those 
(Andreotti et al., 2012). And importantly, as a dynamic configuration having emergent properties and transformational potential LWS also reshapes, continuously, the surrounding systems both at institutional and political levels and thus manifests the broader impact inherent to social innovation (see Andreotti \& Mingione, 2016; TEPSIE, 2014).

\section{Research design}

The article aims to identify the factors related to the emergence of social welfare innovations in rural Finland, and along with that to reflect how to promote the welfare of the rural communities at policy level. This has been pursued through a case study approach focusing on two local welfare systems in western Finland: the municipality of Sievi and the village of Ullava that are approached as the replications of a broader phenomenon, local welfare innovation in rural areas (e.g. Yin, 2014). The selection of these cases is the result of a longitudinal process consisting of two different research projects carried out during 2009-2016 ${ }^{2}$. It began by a nationwide survey looking for rural communities that were worried about their welfare services and had a will to develop them through citizen participation and community orientation. Based on the responses, 18 areas including municipalities, villages, and co-operation districts were selected as mapping areas. At the second phase of the process, the municipality of Sievi and the village of Ullava - two localities which had proceeded towards concrete solutions - were selected for an in-depth analysis of the processes leading to the local welfare innovation.

Sievi and Ullava are both rural settlements situated in the western part of Finland (see Figure 1) but they also have some significant differences and thus offer dissimilar contexts for the development of welfare innovation. Firstly, according to the geographical information-based area classification system (GIS) (Helminen et al., 2014), Sievi belongs to rural heartland areas that exemplify the

\footnotetext{
2 The projects KAMPA (2009-2013) and Rural LWS (2014-2016) both focused on the development of rural welfare services from the base of citizen participation and community orientation. They were financed by the Ministry of Employment and the Economy through the recommendation of the Rural Policy Committee in Finland.
} 
traditional image of Finnish countryside. $38 \%$ of the 1.62 million Finnish rural inhabitants $(11.2 \%$ of the total population) live in rural heartland area which is the most common rural type in terms of the number of population. Rural heartland areas are located relatively remote from big cities but the land use is relatively intensive and there is also often diversified industry. As for Ullava, it represents sparsely populated rural area that covers almost $70 \%$ of the total surface of Finland, but accounts for only $5.4 \%$ of the total population. Characteristics of sparsely populated rural areas include dispersed small settlements located at a distance from one another, low population density and a one-sided economic structure. They are also the most vulnerable to economic and social decline and reduced welfare provision. (See Sireni et al., 2017.)

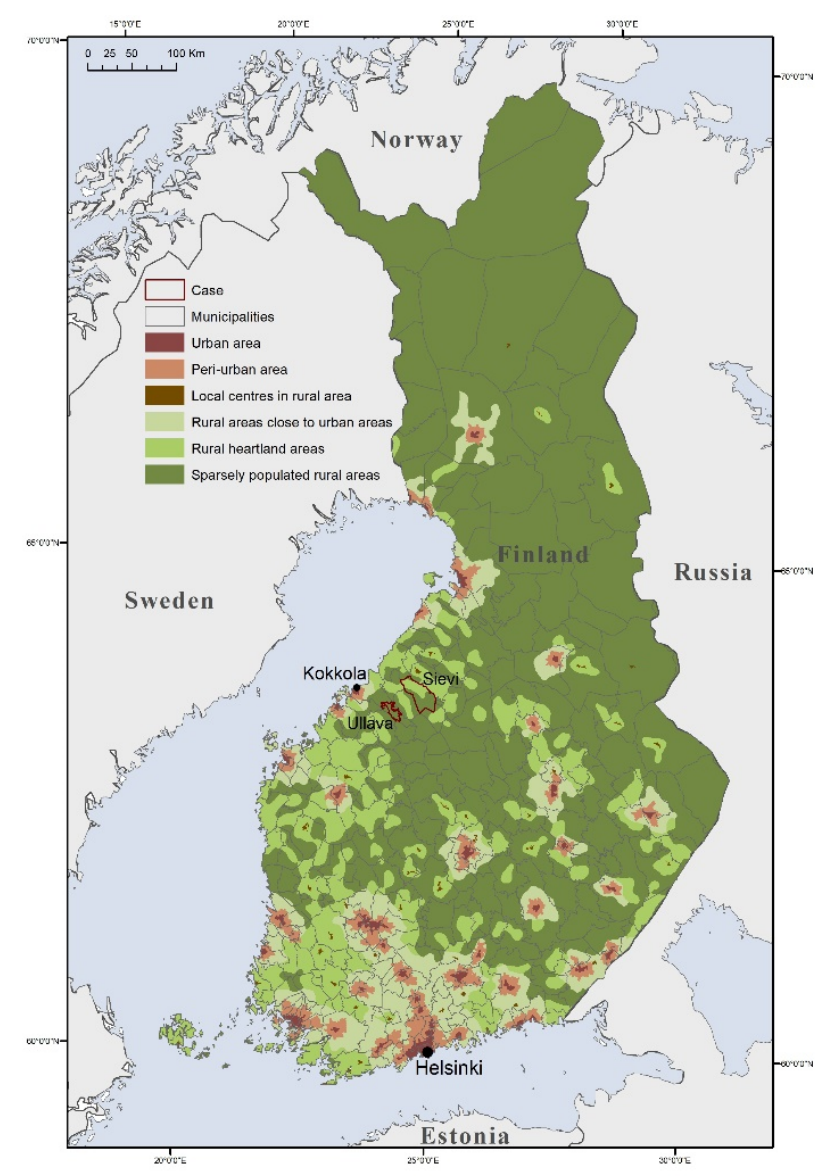

Figure 1. Research localities situated on the map presenting different area types in Finland (Data sources: Finnish Environment Institute, 2010; National Land Survey of Finland, 2008) 
The second noteworthy difference relates to the structural changes that took place in Finland in the spirit of the first phase of the national reform of restructuring local government and public services in 2008. Due to the reform, the responsibility for arranging social and health services in Sievi was shifted from the municipality to the joint municipal authority of "Kallio" founded by four municipalities. As for, the current village of Ullava can be considered as an outcome of the restructuring process; the then independent municipality was legally incorporated into the town of Kokkola at the beginning of 2009 which resulted in the loss of its administrative independence.

Along with the traditional case study, diverse data collection methods, approaching the case from different perspectives and including both qualitative and quantitative information are exploited. The preliminary and more general understanding of the localities as the contexts of welfare innovation is based on the data gathered in local discussion forums during the first phase of the research process (see Table 1). The discussion forums organized by the project were open events to which residents including policy makers and the actors of civil society as well as the representatives of public and private social and health care services were invited. The aim of the forums was to discuss about local welfare needs, the functionality of public services, and the different services and actions provided by local actors. In this regard, the research project also had the characteristic of action research (see Healy, 2001) with the aim of promoting the communication between the public sector and civil society as well as to identify the needs and opportunities for a more citizen-oriented development and provision of welfare services. 
Table 1. The process of data collection

\begin{tabular}{|c|c|c|}
\hline Objective & Action & Participants* \\
\hline \multicolumn{3}{|c|}{ PHASE 1: An overview of rural communities in the turning point of Finnish welfare state } \\
\hline $\begin{array}{l}\text { Identification of rural } \\
\text { communities that have a } \\
\text { will to develop their } \\
\text { welfare services through } \\
\text { citizen participation and } \\
\text { community orientation }\end{array}$ & $\begin{array}{l}\text { 8-9/2009 Nationwide survey with } \\
\text { an open call in cooperation with } \\
\text { local Leader groups, Regional } \\
\text { village associations, Regional Social } \\
\text { Affairs and Health associations and } \\
\text { The regional Centres of Expertise } \\
\text { on Social Welfare }\end{array}$ & $\begin{array}{l}\text { Altogether } 30 \text { responses from } \\
\text { individual rural inhabitants, } \\
\text { representatives of village associations } \\
\text { and other third sector actors, social } \\
\text { and health care professionals }\end{array}$ \\
\hline \multirow{3}{*}{$\begin{array}{l}\text { Mapping of local welfare } \\
\text { services and the } \\
\text { possibilities to develop } \\
\text { them }\end{array}$} & $\begin{array}{l}\text { 10/2009 Discussion forum in Sievi } \\
\text { (duration } 2 \mathrm{~h} 45 \mathrm{~min} \text { ) }\end{array}$ & $\begin{array}{l}20 \text { participants including the mayor of } \\
\text { municipality, local policy makers and } \\
\text { third sector activists }\end{array}$ \\
\hline & $\begin{array}{l}\text { 6/2010 Discussion forum in Ullava } \\
\text { (duration } 2 \mathrm{~h} \text { ) }\end{array}$ & $\begin{array}{l}3 \text { participants including } 2 \text { municipal } \\
\text { authorities and } 1 \text { third sector activists }\end{array}$ \\
\hline & $\begin{array}{l}\text { 1/2012 Discussion forum in Ullava } \\
\text { (duration } 3 \mathrm{~h} 15 \mathrm{~min} \text { ) }\end{array}$ & $\begin{array}{l}12 \text { participants including local policy } \\
\text { makers and third sector activists, a } \\
\text { small entrepreneur, retirees }\end{array}$ \\
\hline \multicolumn{3}{|c|}{ PHASE 2: A case study focusing on the communities with concrete welfare innovations } \\
\hline \multirow{5}{*}{$\begin{array}{l}\text { A deeper understanding } \\
\text { about local innovations } \\
\text { and their development } \\
\text { (key actor interviews) }\end{array}$} & $\begin{array}{l}\text { 9/2014 Interviewee } 1 \text {, Ullava } \\
\text { (duration } 2 \mathrm{~h} 15 \mathrm{~min} \text { ) }\end{array}$ & $\begin{array}{l}\text { Representative of the Ullava service } \\
\text { co-operative }\end{array}$ \\
\hline & $\begin{array}{l}\text { 9/2014 Interviewee } 2 \text {, Ullava } \\
\text { (duration } 1 \mathrm{~h} \text { ) }\end{array}$ & $\begin{array}{l}\text { Manager of the nursing home for } \\
\text { eldery people }\end{array}$ \\
\hline & $\begin{array}{l}\text { 9/2014 Interviewee 3, Ullava } \\
\text { (duration } 1 \mathrm{~h} 30 \mathrm{~min} \text { ) }\end{array}$ & $\begin{array}{l}\text { A public health nurse working in local } \\
\text { health centre }\end{array}$ \\
\hline & $\begin{array}{l}\text { 3/2015 Interviewee } 1 \text {, Sievi } \\
\text { (duration } 1 \mathrm{~h} 15 \mathrm{~min} \text { ) }\end{array}$ & $\begin{array}{l}\text { The initiator of the association of Sievi } \\
\text { Family Service Center }\end{array}$ \\
\hline & $\begin{array}{l}\text { 3/2015 Group interview, Sievi } \\
\text { (duration } 2 \mathrm{~h} 30 \mathrm{~min} \text { ) }\end{array}$ & $\begin{array}{l}5 \text { participants including employees } \\
\text { and the members of the board of the } \\
\text { association }\end{array}$ \\
\hline \multirow[t]{2}{*}{$\begin{array}{l}\text { Familiarization with local } \\
\text { circumstances and the } \\
\text { innovations emerged }\end{array}$} & 8 /2014 A field visit to Ullava & $\begin{array}{l}\text { Researchers with the help of } \\
\text { chairperson of Ullava service co- } \\
\text { operative }\end{array}$ \\
\hline & 3/2015 A field visit to Sievi & $\begin{array}{l}\text { Researcher with the help of the } \\
\text { chairperson of Sievi Family Service } \\
\text { Center }\end{array}$ \\
\hline $\begin{array}{l}\text { An overview of the } \\
\text { sociodemographic } \\
\text { situations of the localities }\end{array}$ & $\begin{array}{l}\text { Gathering statistical data using the } \\
\text { database of Official Statistics of } \\
\text { Finland }\end{array}$ & Researchers \\
\hline $\begin{array}{l}\text { Updating the information } \\
\text { related the localities }\end{array}$ & $\begin{array}{l}\text { Following the news about localities } \\
\text { in the media / Research diary }\end{array}$ & Researchers \\
\hline
\end{tabular}

*Notation: different roles may overlap

At the beginning of the second phase of the research project the development taking place in Sievi and Ullava was followed by conducting interviews with local key actors. The interviewees were selected following the recommendations of the local contact persons with whom the project 
cooperated during the first phase of the research. In the case of Sievi, a group interview was carried out, along with the individual interviews. To gain an in-depth understanding of the local circumstances and the innovation development the researchers conducted field visits to both localities. The notes from the observations made during the visits were documented in a research diary. The overall picture was supplemented by statistical data describing the socioeconomic structures of the localities which, according to Andreotti and Migione (2016), is one of the essential factors defining the substance of LWS. In addition to this, the researchers have constantly followed the news concerning the research localities in the local media during the project period in order to have an updated view on the developments and changes affecting them. The observations were recorded in the research diary.

The data gathered were analysed using a hybrid approach of thematic analysis combining a datadriven inductive approach and a theory-driven deductive approach (see Elo \& Kyngäs, 2008). The process began by the researchers reading through the written material (notes from discussion forums, interviews, and research diary including the findings made during the analysis of statistical data) with the aim to become 'immersed' in it. While reading, the extracts referring to the factors related to the rise of local activity or those illustrating how the local development processes proceeded were highlighted. Next, the selected paragraphs were copied into the locality-specific categorization matrixes (see Table 2) drawn up in accordance with the theory of LWS. The matrixes had two columns of 'needs' and 'resources' which exemplify the two main dimensions of LWS. As for, the rows of the matrixes represented the different conditions influencing the function of LWS: socioeconomic factors, historical and cultural circumstances, interaction between different sectors and actors, and national and local developments. 
Table 2. An example from the locality-specific categorization matrix

\begin{tabular}{|l|l|l|}
\hline \multicolumn{2}{|c|}{ THE CASE OF SIEVI } \\
\hline $\begin{array}{l}\text { The factors related to } \\
\text { the emergence and } \\
\text { function of local } \\
\text { welfare innovations }\end{array}$ & \multicolumn{1}{|c|}{ Welfare needs } & \multicolumn{1}{c|}{ Welfare resources } \\
\hline $\begin{array}{l}\text { Socioeconomic } \\
\text { factors }\end{array}$ & $\begin{array}{l}\text { The share of children in population is } \\
\text { bigger than average in Finland (OFS } \\
\text { 2016) -> There is a need for services } \\
\text { for families with children. }\end{array}$ & $\begin{array}{l}\text { The share of population outside labour } \\
\text { force is bigger than average in Finland } \\
\text { (OFS 2016) -> There are people } \\
\text { resourced with time. }\end{array}$ \\
\hline
\end{tabular}

Since LWS and its formation is defined as a coherent whole and tightly embedded in specific local circumstances (see Andreotti et al., 2012), the data related different cases were treated as separate until the last phase of the analysis when the subcategories were merged, and the common features related to the emergence of welfare innovation were identified.

\section{Results and discussion}

\section{Two local welfare innovations in rural Finland}

As Table 3 shows the challenges commonly related to rural areas such as the decline of population, a lower educational level and a relatively large share of the population outside the labour force are also the characteristics of Sievi and Ullava. However, two significant differences that are in the line with the area classification presented above may be identified. Firstly, the age structure in Sievi is considerably young, even in comparison to the whole of Finland, while Ullava with an increasingly ageing population shares the nationwide problem of sparsely populated areas. Secondly, the economic structure of Ullava is strongly based on primary production and the main sources of livelihood are agriculture, forestry and services, whereas in Sievi there is diverse industry including high technology electronics and machinery companies. Due to good employment opportunities, but also to the influence of revivalist movements that are set against birth control, there are numerous young and large families of children in Sievi which place a strain on the child and family welfare 
services. As for in Ullava, the ongoing plans related to wind energy production and the mining industry has increased hope for the future among the residents.

Table 3. Socioeconomic and demographic structure of the research localities in comparison with Finland as a whole (OFS 2016)

\begin{tabular}{|c|c|c|c|}
\hline & Municipality of Sievi & Village of Ullava & Finland in total \\
\hline $\begin{array}{l}\text { Population } 2015 \\
\text { Density }\left(\mathbf{n} / \mathbf{k m}^{2}\right)\end{array}$ & $\begin{array}{c}5124 \\
6.5 / \mathrm{km}^{2}\end{array}$ & $\begin{array}{c}882 \\
5.4 / \mathbf{k m}^{2}\end{array}$ & $\begin{array}{l}5487308 * \\
18.1 / \mathbf{k m}^{2}\end{array}$ \\
\hline $\begin{array}{l}\text { Change of population } \\
-2005-2010 \\
2010-2015\end{array}$ & $\begin{array}{l}+2.3 \% \\
-2.6 \%\end{array}$ & $\begin{array}{l}-4.9 \% \\
-6.8 \%\end{array}$ & $\begin{array}{l}+2.3 \% \\
+2.1 \%\end{array}$ \\
\hline $\begin{array}{l}\text { Gender distribution } \\
2013 \text { (Female/Male \%) }\end{array}$ & $\begin{array}{l}\text { F: } 48.5 \% \\
\text { M: } 51.5 \%\end{array}$ & $\begin{array}{l}\text { F: } 48.9 \% \\
\text { M: } 51.1 \%\end{array}$ & $\begin{array}{l}\text { F: } 50.8 \% \\
\text { M: } \mathbf{4 9 . 2 \%}\end{array}$ \\
\hline $\begin{array}{c}\text { Average age } 2015 \\
-\quad<16 \text { years } \\
-\quad 16-64 \\
-\quad 64<\end{array}$ & $\begin{array}{l}37.1 \text { years } \\
-\quad \mathbf{2 8 . 6} \% \\
-\quad \mathbf{5 4 . 3} \% \\
-\quad 17.1 \%\end{array}$ & $\begin{array}{l}43.3 \text { years } \\
-\quad 19.7 \% \\
-\quad 56.9 \% \\
-\quad 23.4 \%\end{array}$ & $\begin{array}{l}42.0 \text { years } \\
-\quad 17.4 \% \\
-\quad 62.1 \% \\
-\quad 20.5 \%\end{array}$ \\
\hline $\begin{array}{l}\text { Educational levels } 2014 \\
\text { (inhabitants } \geq 18 \text { years) } \\
-\quad \text { Basic** } \\
-\quad \text { Secondary } \\
-\quad \text { Higher }\end{array}$ & $\begin{array}{ll}- & 31.6 \% \\
- & \mathbf{5 8 . 0} \% \\
- & \mathbf{1 0 . 4} \%\end{array}$ & $\begin{array}{ll}- & 43.2 \% \\
- & 49.6 \% \\
- & 7.2 \%\end{array}$ & $\begin{array}{l}-\quad 26.9 \% \\
-\quad 52.6 \% \\
-\quad 20.5 \%\end{array}$ \\
\hline 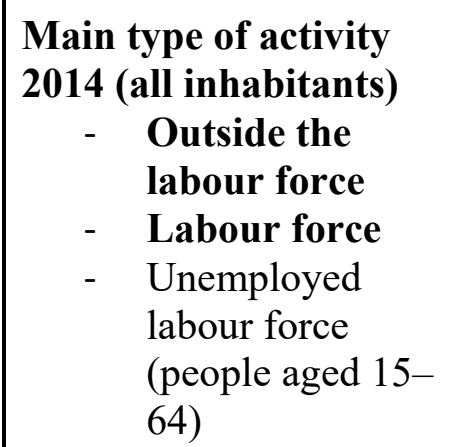 & $\begin{array}{l}-\quad \mathbf{6 1 . 0} \% \\
-\quad \mathbf{3 9 . 0} \% \\
-\quad 5.2 \%\end{array}$ & $\begin{array}{l}-\quad \mathbf{5 4 . 5} \% \\
-\quad \mathbf{4 5 . 5 \%} \\
-\quad 5.6 \%\end{array}$ & $\begin{array}{l}-\quad \mathbf{5 1 . 8} \% \\
-\quad \mathbf{4 8 . 2} \% \\
-\quad 6.6 \%\end{array}$ \\
\hline $\begin{aligned} & \text { Workplaces } \\
&- \text { Primary } \\
& \text { production } \\
&- \text { Processing } \\
&- \text { Services }\end{aligned}$ & $\begin{array}{l}-\quad 9.6 \% \\
-\quad 58.3 \% \\
-\quad 32.1 \%\end{array}$ & $\begin{array}{l}-\quad 30.2 \% \\
-\quad 17.2 \% \\
-\quad 52.7 \%\end{array}$ & $\begin{array}{l}-\quad 2.9 \% \\
-\quad 21.6 \% \\
-\quad 75.5 \%\end{array}$ \\
\hline
\end{tabular}

*The mean value of the Finnish municipalities is 17310 inhabitants.

** In Finland nine years of comprehensive school education are obligatory. 
Sievi - a community focusing on families with children

Based on the results of the discussion forum organized in 2009 the residents of Sievi were satisfied both with the number and the availability of public-school services, including seven village schools (grades 1-6) along with a secondary school and upper secondary school in the centre of the municipality. However, what they were dissatisfied with was the basic social and health services. This view is based on the changes that took place when the joint authority of Kallio began to organize social and health services. Among the first measures Kallio addressed was the harmonization of service structures which, in the case of Sievi, led to a significant reduction in home help services for families with children. The participants of the discussion forum considered it as evidence that while this was driven by the aim of making financial savings at the same time it revealed much about the incapability of a larger organization to take into consideration special local characteristics:

"It is that those working in the administration of Kallio; they don't understand our situation”. (Discussion forum Sievi, 2009)

The launch of collective action may be traced to a moment when a single resident expressed his concern about the challenges the families with several children were facing in their everyday life:

"I noticed that there were many mothers with big families who were very tired. Because I don't have any small children in my family, I decided to ask some families with children living in my neighborhood how they were doing. One mother told me how difficult it is to get any help. They had just moved to Sievi and had no family around. That's when I decided that something has to be done." (Interviewee 1, Sievi)

Through being involved in municipal politics and church activities the person possessed a good understanding of the situation of Sievi, had good social networks, and knowledge of how to promote the undertaking. At first, he made a proposal to the municipal council about hiring a home help for families, but this was rejected. However, as the need was so obvious, he decided together with few others, to set up the association of "Sievi Family Service Center" (Sievin 
perhepalvelukeskus). The purpose of the association founded in 2013 is crystallised by a member of the executive board as follows:

"Our idea is that the services provided by the association are aimed at everybodycrossing the various political and religious divisions. We want to get rid of the stigma of being a weak person if you need help. For many of the families it is just the feeling of belonging to something that is important; knowing that there are people around who will carry you through difficult times. This is a humane way to care for each other. And it so cheap compared to the costs of reconstructive services which the public sector is obligated to organize when things have gone too far." (Group interview, Sievi)

To begin with, the association carried out a survey to find out what kind of support the families needed. Most pressing was the need of home help and peer support, especially for stay-at-home mothers. To meet these needs the association set up a "Family House" -centre which is located in an apartment offered free of charge by the municipality. In the beginning, the main source of income was the start-up funding provided by the local Leader group and a donation made by the mayor of Sievi. In addition, the association received financial support from the church and local businesses, which were invited to take part by a "challenge campaign" organized in the local newspaper. At the end of our research in 2016, the activities of the "Family House" -centre include a "family café" that is open once a week and a short-term childcare service available twice a week. In addition, the association offers a service they call "old-style home help" which includes help with housework and childcare as well as support in solving different problems the families may face with parenting. The association has two paid employees whose salary costs are split between the municipality and the association. However, the struggle with insufficient financial resources remains an everyday challenge. Once a year it organizes a larger seminar where experts from different fields, including local decision-makers and researchers, are invited to discuss topical issues related to the welfare of the families. According to the representative of the association the goal of these meetings is both to get information and to make the services provided by the association known to all the local residents and those in positions of power: 
"That's how we reach those who are not yet familiar with our operations and also raise public debate about the issues that are important to us." (Group interview, Sievi)

The association has continued to develop the activities in close co-operation with the municipality, the church, and other third sector organizations. The founder members are still actively involved, but over time the families using services have increasingly taken responsibility.

\section{Ullava - a village struggling for survival}

In the framework of the reform of local government and services in the beginning of 2009 , the hundred-year-old rural municipality of Ullava, became the most remote neighborhood of the old trading and industrial town of Kokkola. The level of the basic public services available in Ullava located about 50 kilometers from the downtown area are quite good and includes two elementary schools (grades 1-6) and kindergartens, a health centre, residential care services for the elderly and a leisure centre within the library. However, with the consolidation of municipalities, uncertainty concerning the future of the village began to increase among the residents. They were aware of the common pattern of development in many Finnish villages situated far from city centers that have first lost their basic services and thereafter their residents.

The representative of the Ullava service co-operative saw that the first concrete warning sign that made the residents "get down to business" took place when the shop in the village centre closed its doors in November 2010:

"When the village shop was closed, we put two and two together and decided that from now on we have to do things by ourselves. We saw the village shop as a buffer to stop all services gradually moving to the centre of Kokkola." (Interviewee 1, Ullava)

The result of the common negotiation process that took place among the villagers, both unofficially during day-to-day encounters and more officially in the form of a village meeting arranged by the initiator group, was the foundation of the Ullava service co-operative in February 2011. Its first task 
was to reopen the village shop. Since this was fulfilled the co-operative continued to develop other services the villagers valued including the branch office of a pharmacy and a petrol station. The guiding idea behind these developments has been the view that if people must search for only one service outside of the village, the risk is that they will obtain all other services from there as well.

Currently, the village shop provides employment for four shop assistants and opportunities for practical work-training for those suffering from long-term unemployment. However, a very central role is played by active villagers of different ages and life situations who volunteer to undertake various tasks ranging from management to the shelving of items on sale. Though it is mainly about volunteering the actors in Ullava highlight the importance of vision and a strategic plan:

"It's the board of the co-operative that organizes different things. When choosing new board members, we try to pick people with different skills and knowledge - such as management of finances, personnel management, communication skills and local knowledge. It's also important to make sure that in addition to experience we always have some new people who are willing to take charge. That's how we make sure that things won't get too stressful for those involved and that we will always have some fresh ideas up our sleeves.” (Interviewee 1, Ullava)

In general, the success of the co-operative activity has also brought about a new kind of activism in other fields such as municipal policy, even to the extent that the chairperson of Kokkola town board for years 2017-2019 comes from Ullava. Furthermore, people in Ullava have come to see that the threat to their livelihood they experienced led them find the identity they had once lost:

“When one lives in the countryside, you're in a way forced to play ball with others whether you like it or not. That's how we used to act for decades but then for some reason we almost forgot it." (Discussion forum Ullava, 2010) 
At the end of our research, the future of Ullava looked quite bright compared with where everything began. The service level of the village is diverse and most importantly, from the perspective of young families, Ullava has also proved itself to be an attractive place to settle.

\section{The conditions contributing the emergence of local welfare innovation}

The two case studies show that local welfare innovations were developed with a focus to find new ways to meet 'pressing unmet needs' (see Mulgan et al., 2007). As per the holistic interpretation of social innovation (see Moulaert et al., 2014; TEPSIE, 2014), they both deliver social value that is primarily concerned with the quality of life, solidarity and well-being. This includes the provision of services relevant to daily life but more important - doing this in a way that contributes to the development of new social relationships and collaborations crossing the different sectoral and organizational boundaries and thus strengthening the sense of community.

Both in Sievi and in Ullava, the initial incentive for welfare innovation may be identified in the response to decisions made by the government that viewed rural areas unfavourably. The renewal of governmental and service structures that in turn have resulted in the withdrawal of services and the weakening of municipal democracy at the local level exemplify the 'vulnerability category' of policy change which according to Freshwater (2015) is one of the four risk types threatening rural communities. The policy risks are "supplemented" by dominant societal developments including the climate change, global economic uncertainty and the increased sense of insecurity. Among the residents of rural areas, the current developments as well as the prospects related to them have generated a fear that there will be no positive turn in the future either. This leaves the rural communities with two options: to change or to atrophy. Regarding the cases studied here, the launch of local activity towards the change was strongly driven by an external threat that got a tangible form in the local context. However, it was the controllable size of shocks in relation to local resources that made it possible to turn them into an objective of collective action. 
As Byrne (2005, p. 103) stated, in the real social world, the structure and actions of a social system are not just a product of contemporary agents and actions. Instead, they are also embedded in and shaped by a history which is present as they act, and which in turn, is shaped and changed by their actions. In this sense two significant factors related to the cases studied here may be identified. The communal culture which provides a foundation for local collaboration reflects the legacy of agrarian society with the tradition of joint work activities, co-ownership, and co-operatives as well as active third sector organisations and various religious communities (Hyyryläinen, 2000). As for the identity of an independent municipality as a self-governing unit has resourced the community with people who have experience in local development and decision making. It enables them to review ongoing developments from a broader perspective as well as makes them conscious of the necessity of maintaining a close liaison with each other. This comes close to what Putnam (2000) referred as bridging social capital: the bonds of connectedness laid down over time that are formed across diverse groups and individual people and that contribute to the ability of a system to respond to adversity.

However, not all rural communities with a similar history and challenges of the same kind have the ability for self-organisation and the creation of a new order. The strengths of Sievi and Ullava are the demographic structures that despite the challenges are versatile enough as well as diverse economic structures with bright future prospects. In this respect, the situation in Sievi and Ullava is beneficial in comparison to many other rural localities. In addition, it is also about the ability of a local community to recognise diverse needs and to use existing strengths - to be open enough and thus able to pool both the individual and organisational resources it has. As indicated by Andreotti et al. (2012), social diversity, characterized by various and even contrary needs and ambitions, may also turn into a source of conflict instead of being a resource. The answer to why this is not the case 
in Sievi and Ullava could lie in what Bock (2016; see also Robinson \& Carson, 2016) has identified in addition to social capital conducive to local development and a positive adaptability to change alike. This involves factors such as entrepreneurial culture, the satisfactory level of services, and the structures of local democracy that offer possibilities to influence. The fact that despite the differences, the demographic structure of the localities is still quite homogeneous from the standpoint of racial and cultural diversity should neither be overridden. This would challenge the sense of communal identity totally differently as described by Forsander (2004) in the context of Nordic welfare states.

\section{About the generalisation and usability of the results}

The cases presented here provide a narrow glimpse of local welfare innovations in Finnish rural areas and the factors contributing to their emergence. One may rightly question if these micro level cases have any broader relevance, and if they at all fulfil the criterion of social innovation or have the properties of societal transformation. Regarding this, we like to present two possible viewpoints. Firstly, the complexity thinking underlying the theory of LWS is based on a view that knowledge is rather contextual than universal. In the case, a comparative approach with an aim to identify the overarching and distinctive features of the cases is seen as a way towards a deeper understanding about the studied phenomenon (see Byrne, 2005). However, whilst we recognize the challenges related to the generalisation of the results we see, in reference to Robson (2002), that close cooperation with local actors, the long-lasting research process, as well as the exploitation of different methods and data sources are factors that have a positive impact on the reliability of the study. Secondly, concerning the broader impact of the welfare innovations studied here, we turn to Evers and Brandsen (2016) who applying the metaphor of 'a message' emphasized the importance to look at more closely grassroots level social innovations as there might be many lessons to be learned. 


\section{Conclusion}

To sum up the, the emergence of local social innovations in the context of local welfare systems in rural Finland is the result of a combination of external causes and local resources. In both cases of the study an incentive to local initiative may be traced to the ongoing changes in the context of the national welfare policy. However, the external pressure alone is not enough but the creation of innovative solutions calls for a sense of community. This includes diverse social networks and a shared vision of common goals that - in an ideal world - is both concrete and practical. As for, the preparedness to act and cooperate is related to a diverse enough community structure that offers various resources and different skills and, most importantly, people who are willing to take charge on common issues. These crucial factors may be crystalized into the concepts of social capital and local governance that are generally seen as the essential ingredients of community resilience and further local social innovations: the ability of a community to react to disruptive events not only by striving to rebuild the past but also by searching for new opportunities.

So, what we can learn from the cases studied here? The defining characteristics of social innovation are that they create new combinations from existing elements. Consequently, what is needed to promote local welfare innovations, is a long-term strategy for how to proceed and tap the resources available in a versatile way: a new set of actions that has its roots in what already is available and keep an eye on the future. In this regard, we call for a "territorial governance" perspective that brings together place-based approach (see Barca, McCann, \& Rodriguez-Pose, 2012) and multilevel governance and reflects the desire for a better integration and participation of various stakeholders. Furthermore, the more networked approach across all levels of governance and through different societal sectors makes it possible to recognize the divergent consequences of policy implementation - both projected and unexpected as noted also by Chevalier and Vollet 
(2018) in their study focusing on social innovations that have arisen under the LEADER

programme. In the context of welfare policy, territorial governance emphasizes a comprehensive approach which alongside focusing on the divergent welfare needs of individual people considers the broader viability or sustainability dimension of the communities and regions and works towards it in tight collaboration with other policy fields as well as the actors from different societal sectors (Well \& Schmitt, 2015).

Reviewing and organizing the governance in a territorial perspective provides a workable framework for the promotion of local welfare innovations. However, this is not enough. Attention should also be directed towards how to involve people at the local level. We see that there is a need for a more ideological shift from the oversimplified efficiency agenda of the neoliberal thinking towards an approach where public services in general - not only those that are withdrawing - are considered as an arena to stimulate, manifest, and cultivate the participatory form of democracy (see Evers, 2010). A society based on shared ambition and reciprocal collaboration provides a good breeding ground for various innovative welfare solutions to flourish. However, it must be accepted that despite all the support and inspiring examples not all communities have the preconditions to be innovative enough and there is still need for a welfare state that is just in terms of redistribution and recognition (see MacKinnon \& Derickson, 2012).

\section{References}

André, C., \& García C. (2014). Local Public Finances and Municipal Reform in Finland. OECD Economics Department Working Papers, No. 1121, OECD Publishing, Paris. https://doi.org/ 10.1787/5jz2qt0zj024-en.

Andreotti, A., Mingione, E., \& Polizzi E. (2012). Local welfare systems: A challenge for social cohesion. Urban Studies, 49(9), 1925-1940. https://doi.org/10.1177/0042098012444884.

Andreotti, A., \& Mingione, E., (2016). Local welfare systems in Europe and the economic crisis. European Urban and Regional Studies, 23(3), 252-266.

https://doi.org/10.1177/0969776414557191. 
Barca, F., McCann, P., \& Rodriguez-Pose, A. (2012). The case for regional development intervention: Place-based versus place-neutral approaches. Journal of Regional Science, 52(1), 134152. https://doi.org/10.1111/j.1467-9787.2011.00756.x.

Bock, B.B. (2016). Rural Marginalisation and the Role of Social Innovation; A Turn Towards Nexogenous Development and Rural Reconnection. Sociologia Ruralis, 56 (4), 552-573. https://doi.org/0.1111/soru.12119.

Brandsen, T., Evers, A., Cattacin, S., \& Zimmer, A. (2016). Social Innovation: A Sympathetic and Critical Interpretation. In T. Brandsen, S. Cattacin, A. Evers, \& A. Zimmer (Eds.), Social Innovations in the Urban Context. Cham: Springer International Publishing.

Byrne D. (2005) Complexity, Configurations and Cases. Theory, Culture \& Society, 22(5), 95-111. https://doi.org/10.1177/0263276405057194.

Cheshire, L., Esparcia, J., \& Shucksmith, M. (2015). Community resilience, social capital and territorial governance. Ager, 18, 7-II. https://doi.org/10.4422/ager.2015.08.

Chevalier, P., \& Vollet, D. (2018) LEADER 2007-2013: An innovation dependent on local and national institutional arrangements? Some European illustrations. Regional Science \& Policy Practice, 29 2018, 1-16. https://doi.org/10.1111/rsp3.12156.

Elo, S., \& Kyngäs, H. (2008). The qualitative content analysis process. The qualitative content analysis process. Journal of Advanced Nursing, 62(1), 107-115. https://doi.org/10.1111/j.13652648.2007.04569.x.

Esping-Andersen, G. (1990). The three worlds of welfare capitalism. Cambridge: Polity Press.

Evers, A. (2010). Civicness, civility and their meanings for social services. In T. Brandsen, P. Dekker, \& A. Evers (Eds.), Civicness in the governance and delivery of social services, 41-65. Germany: Nomos Verlagsgesellschaft, Baden-Baden.

Evers, A., \& Brandsen, T. (2016). Social innovations as messages: Democratic experimentation in local welfare systems. In T. Brandsen, S. Cattacin, A. Evers, \& A. Zimmer (Eds.), Social Innovations in the Urban Context, 161-180. Cham: Springer International Publishing.

Finnish Environment Institute (2010). YKR urban-countryside classification. https://avaa.tdata.fi/web/paituli/metadata.

Forsander, A. (2004). Social capital in the context of immigration and diversity: Economic participation in the Nordic welfare states. Journal of International Migration \& Integration, 5(2), 207-227. https://doi.org/10.1007/s12134-004-1010-1.

Freshwater, D. (2015). Vulnerability and resilience: Two dimensions of rurality. Sociologia Ruralis, 55(4), 497-515. https://doi.org/10.1111/soru.12090.

Haverinen, R., \& Ilmarinen, K. (Eds.). (2008). Hyvinvoinnin arki maaseudulla. Tekeviä käsiä ja tietoteknologiaa. [Everyday Welfare Services in Rural Areas. Skilled Hands and Information Technology]. Helsinki: Rural Policy Commitee. 
Healy, K. (2001). Participatory action research and social work: A critical appraisal. International Social Work, 44 (1), 93-105. https://doi.org/10.1177/002087280104400108.

Helminen, V., Nurmio, K., Rehunen, A., Ristimäki, M., Oinonen, K., Tiitu, M., Kotavaara, O., Antikainen, H., \& Rusanen, J. (2014). Kaupunki-maaseutu-alueluokitus. Paikkatietoihin perustuvan alueluokituksen muodostamisperiaatteet. [Urban-rural-classification. The basis for development of geographical information-based area classification system]. Reports of Finnish Environment Institute, 25:2014.

Hyyryläinen, T. (2000). Kylätoiminnan perinne sosiaalisena pääomana. [The tradition of village action as a social capital]. In T. Hyyryläinen, \& P. Rannikko (Eds.) Eurooppalaistuva maaseutupolitiikka. Paikalliset toimintaryhmät maaseudun kehittäjinä, 109-119. Tampere: Vastapaino.

Häikiö, L. 2010. The Diversity of Citizenship and Democracy in Local Public Management Reform. Public Management Review, 12(3), 363-384. https://doi.org/10.1080/14719030903286649.

Häikiö L., Fraisse, L., Adam, S., Jolanki, O., \& Knutagård, M. (2017). The Janus face of social innovation in local welfare initiatives. In F. Martinelli, A. Anttonen, \& M. Mätzke (Eds.), Social Services Disrupted: Changes, Challenges and Policy Implications for Europe in Times of Austerity, 281-301. Cheltenham: Edward Elgar. https://doi.org/10.4337/9781786432117.00024.

Hänninen, S., \& Silvasti, T. (2010). Giving up farming and the welfare state restructuration in Finland. In Milbourne, P. (Ed.), Welfare reform in rural places: Comparative perspectives 151171. Bingley: Emerald.

Kröger, T. (2011). Retuning the Nordic welfare municipality. Central regulation of social care under change in Finland. International Journal of Sociology and Social Policy, 31(3/4), 148-159. https://doi.org/10.1108/01443331111120591.

Kuivalainen, S., \& Niemelä, M. (2010). From universalism to selectivism: the ideational turn of the anti-poverty policies in Finland. Journal of European Social Policy, 20(3), 263-276. https://doi.org/10.1177/0958928710364432.

MacKinnon, D., \& Derickson, K. (2012). From resilience to resourcefulness: A critique of resilience policy and activism. Progress in Human Geography, 37(2), 253-270. https://doi.org/10.1177/0309132512454775.

Matthies, A-L., Kattilakoski, M., \& Rantamäki, N. (2011). Citizens' participation and community orientation - indicators of social sustainability of rural welfare services. Nordic Social Work Research, 1(2), 125-139. https://doi.org/10.1080/2156857X.2011.613575.

Matthies, A-L., \& Rantamäki, N. (Eds.). (2013). Hyvinvointitalkoot - Miten kuntalaisten osallistuminen tukee palveluita. [Joint Work for Welfare: How the Participation of the Residents Will Contribute the Services]. Kokkola: University of Jyväskylä, Kokkola University Consortium Chydenius \& KAMPA-project. 
Milbourne, P. (2010). Scaling and spacing welfare reform: Making sense of welfare in rural places. In Milbourne, P. (Ed.), Welfare Reform in Rural Places: Comparative Perspectives, 1-17. Bingley: Emerald Group Publishing Limited.

Montgomery, T. (2016). Are social innovation paradigms incommensurable? Voluntas, 27(4), 1979-2000. https://doi.org/10.1007/s11266-016-9688-1.

Moulaert, F., MacCallum, D., Mehmood, A., \& Hamdouch, A. (2014). The international handbook on social innovation: Collective action, social learning and transdisciplinary research. Cheltenham, Glos, UK: Edward Elgar.

Mulgan G., Tucker S., Ali R., \& Sanders B. (2007). Social Innovation: What It Is, Why It Matters and How It Can Be Accelerated. Working Paper. Said Business School, Oxford University, Oxford.

Murray R., Caulier-Grice, J., \& Mulgan G. (2010). The open book of social innovation. London: The Young Foundation.

National Land Survey of Finland (2008). Administrative borders. https://avaa.tdata.fi/web/paituli/metadata.

Nicholls, A., \& Murdock A. (2012). Social Innovation: Blurring Boundaries to Reconfigure Markets, Palgrave Macmillan.

Niemelä, M., \& Saarinen, A. (2012). The role of ideas and institutional change in Finnish public sector reform. Policy \& Politics, 40(2), 171-191. https://doi.org/10.1332/147084411X581871.

Närhi, K., \& Kokkonen, T. (2014). Transformation of Participation Politics and Social Citizenship in the Finnish Welfare Governance. In A-L. Matthies, \& L. Uggerhøj (Eds.), Participation, marginalization and welfare services - concepts, politics and practices across European countries, 95-111. Farnham: Ashgate.

OSF (2016). Population Structure [Online: Official Statistics of Finland]. Available at: http://www.stat.fi/til/vaerak/index_en.html [accessed 9 May 2017].

Putnam, R.D. (2000). Bowling Alone: The Collapse and Revival of American Community. New York: Simon and Schuster.

Robinson, G., \& Carson, D. (2016). Resilient communities: transitions, pathways and resourcefulness. The Geographical Journal, 182 (2), 114-122. https://doi.org/10.1111/geoj.12144.

Robson, C. (2002). Real world research. Oxford: Blackwell.

Satka, M., \& Hämeenaho, P. (2015). Finnish eldercare services in crisis: the viewpoint of rural home care workers. Nordic Social Work Research, 5(1), 81-94. https://doi.org/

$10.1080 / 2156857 X .2014 .943265$.

Sireni, M., Halonen, M., Hannonen, O., Hirvonen, T., Jolkkonen, A., Kahila, P., Kattilakoski, M., Kuhmonen, H-M., Kurvinen, A, Lemponen, V., Rautiainen, S., Saukkonen, P., \& Åström, C. (2017). Maaseutukatsaus 2017. [Rural Survey 2017]. Helsinki: Publications of the Ministry of Agriculture and Forestry 7/2017. 
TEPSIE (2014). Social innovation theory and research: a guide for researchers. A deliverable of the project: "The theoretical, empirical and policy foundations for building social innovation in Europe" (TEPSIE), European Commission - 7th Framework Programme, Brussels: European Commission, DG Research.

Valtioneuvosto (2018). Regional government, health and social service reform. https://alueuudistus.fi/en/general-information-reform, accessed August 21, 2018.

Well, L. v., \& Schmitt, P. (2015). Understanding territorial governance: conceptual and practical implications. Europa Regional, 21.2013(4), 209-221. https://nbn-resolving.org/urn:nbn:de:0168ssoar-457127.

Yin, R. K. (2014). Case study research: Design and methods (5th edition.). Los Angeles: SAGE. 